\title{
Impact of Mobile Applications for a Lima University in Pandemic
}

\author{
Carlos Diaz-Núñez ${ }^{1}$, Gianella Sanchez-Cochachin ${ }^{2}$, Yordin Ricra-Chauca ${ }^{3}$, Laberiano Andrade-Arenas ${ }^{4}$ \\ Facultad de Ciencias e Ingeniería \\ Universidad de Ciencias y Humanidades
}

\begin{abstract}
The current global pandemic situation has forced universities to opt for distance education, relying on digital tools that are currently available, such as course management platforms like Moodle, videoconferencing applications like Google Meet or Zoom, or instant messaging apps like WhatsApp. In this study it is detailed that these tools have made virtual education an effective alternative to provide education without having a physical space where teachers and students can concentrate. In addition, this document shows that in this form of teaching learning it is not necessary to have a computer, it is enough to have a cell phone to access this type of education in Peru, since most of the country's homes have a smartphone . Both students and teachers affirm that, although a little more time is invested than usual, this teaching method is satisfactory. The result obtained is that the use of mobile applications plays a very important role in virtual classes since the vast majority of students use the cell phone. In conclusion, teaching and learning in higher university education with the use of mobile applications, both teachers and students said that it was of great help due to the interaction through communication with WhatsApp, zoom, Google meet, among others. In addition, being in constant communication with the students through the applications strengthened the teaching.
\end{abstract}

Keywords-Higher education; internet connection; mobile applications; pandemic; university

\section{INTRODUCTION}

At the European level, m-learning is becoming increasingly common in higher education. According to the report La Sociedad de la Información en España 2016 (study prepared by Fundación Telefónica), smartphone sales in Spain reached 334.9 million in the first quarter of 2016. These figures represent 87\% (data taken from the Ditrendia 2016 Report: Mobile in Spain and in the World) of the country's total number of mobile phones. In terms of connectivity, $92 \%$ of Internet users access the Internet from their smartphones [1]. In a study Wai, $\mathrm{Ng}$, Chiu showed that $84.7 \%$ of university students used these applications for training purposes. They also stated that they would like to use mobile applications to search for learning materials and share information [2]. Some Latin American countries, such as Mexico and Colombia, are among the top ten countries that use these platforms [3].

With the complementary of the Information Technologies and with the easy access to Internet, it has been possible to be viable many of the things that needed a presential treatment, now it is enough to have an application in the mobile or to enter a page in Internet, to make different transactions in real time. Banks, stores, even in the area of medical care, have implemented applications for their attention from anywhere in the world.
Currently, the use of mobile devices in Peru, the majority of people who have them, which in turn presents great advantages in terms of portability. This type of e-learning is known as mlearning (mobile learning) [4]. According to a study by Futuro Labs in 2014, young people between the ages of 20 and 29 (18\% of the Peruvian population), an age range in which most are university students, have mobile devices and use them on social networks [5].

In a 2017 study on m-learning student performance using the Google Classroom application, $86 \%$ of students found that it helped them improve their academic performance [6]. Another study in 2019 shows that m-learning helps university students to perform and speak in English [7].

In these times, conventional education is having gaps when it comes to teaching, since, due to factors beyond their control, the immobilization of people decreed by many governments worldwide has left them only at home, unable to go out, much less to places where many people are concentrated. Education at any level has been affected in the delivery of classes.

With the above, a virtual learning system makes e-learning the only option for providing the educational service[8]. It would also turn remote interaction into local interaction, decrease network bottlenecks and accelerate response speed [9].

E-learning and the new vision of the use of technology, provides the necessary tools of technological communications, to make the process of teaching - learning effective and viable [10].

The objective of this article is to demonstrate the impact that mobile applications had on the teaching process at a university in northern Lima in times of pandemic.

The structure of the article is formed as follows: in Section II review of the literature, explaining the background, in Section III we focus on the methodology, where we place the steps to follow, in Section IV results and discussions where the results are discussed obtained and finally Section $\mathrm{V}$ which is the conclusions and future work.

\section{Literature REVIEW}

Currently, in times of pandemic, teaching is remotely where the use of mobile applications is relevant in education [11]. In rural areas, compared to urban areas, internet connectivity is a problem [12],In other words, what is favored in education are generally those who can access a payment plan for the use of the internet.On the other hand, the use of digital tools by students and teachers must be able to teach remote learning [13]. Students nowadays use WhatsApp more 
frequently, where it is a means of communication between teachers and students, to coordinate tasks, consultations among others [14]. In addition, the use of zoom as a videoconference by both the teacher and the students, their training is important for both to know all the benefits of zoom, such as screen sharing, uploading files among others [15]. Also, the moodle platform is widely used in university education where it has its benefits for use by students and teachers. This platform allows asynchronous and synchronous interaction [16]. The Google meet is a videoconference like the zoom but each one of it has its own advantages and disadvantages, such as computer security and its elements that make it up to interact with students [17].There are other videoconferences such as Jitsi but it is not as secure as Zoom. It is also observed in students who mostly use cell phones, where they have downloaded the zoom, Google meet among others. However, there are students who use the computer that is different to the use of the cell phone. Therefore, the teacher must adapt to teach the students remotely with a mobile phone and a computer. This requires training in the use of mobile applications and digital tools [18].The LMS (learning management system) allows to have an adequate management in the teaching-learning process since you can upload files to the platform and download them in your mobile application and this is also approved by a Web Master that the administrator comes to do. of the educational entity [19] .Mobile applications in times of pandemic have allowed the use of the internet to grow exponentially due to the use of students, however those who do not benefit from the use of the mobile are the neediest students who are in poverty or extreme poverty.

\section{METhODOLOGY}

Next, the relevant aspects that directly influence the development of virtual education will be analyzed, such as the connectivity in the country and how many people have a smartphone- In addition, the important points of technological tools that flow in virtual education will be described. Such as Zoom, WhatsApp, Meet or Moodle Mobile applications.

\section{A. Survey}

This research will apply a survey to 15 students and 6 teachers of the University of Sciences and Humanities in the seventh semester of the career of Systems and Computer Engineering, will be conducted through a survey using Google Form tools.

The survey that will be applied to teachers and students, will use a structure in two blocks: questions on the mastery of technologies and computer resources; and questions on mobile devices in learning. The link to the forms will then be presented:

Teacher survey: https://forms.gle/hPzRAR2HgASZSUPa7

Student survey: https://forms.gle/8PYtamsVZ4U6y87H8

\section{B. Connectivity in Peru}

Internet connection is a key part of effective distance education. According to the National Institute of Statistics and Informatics (INEI), mentioned in Fig. 1, the total percentage

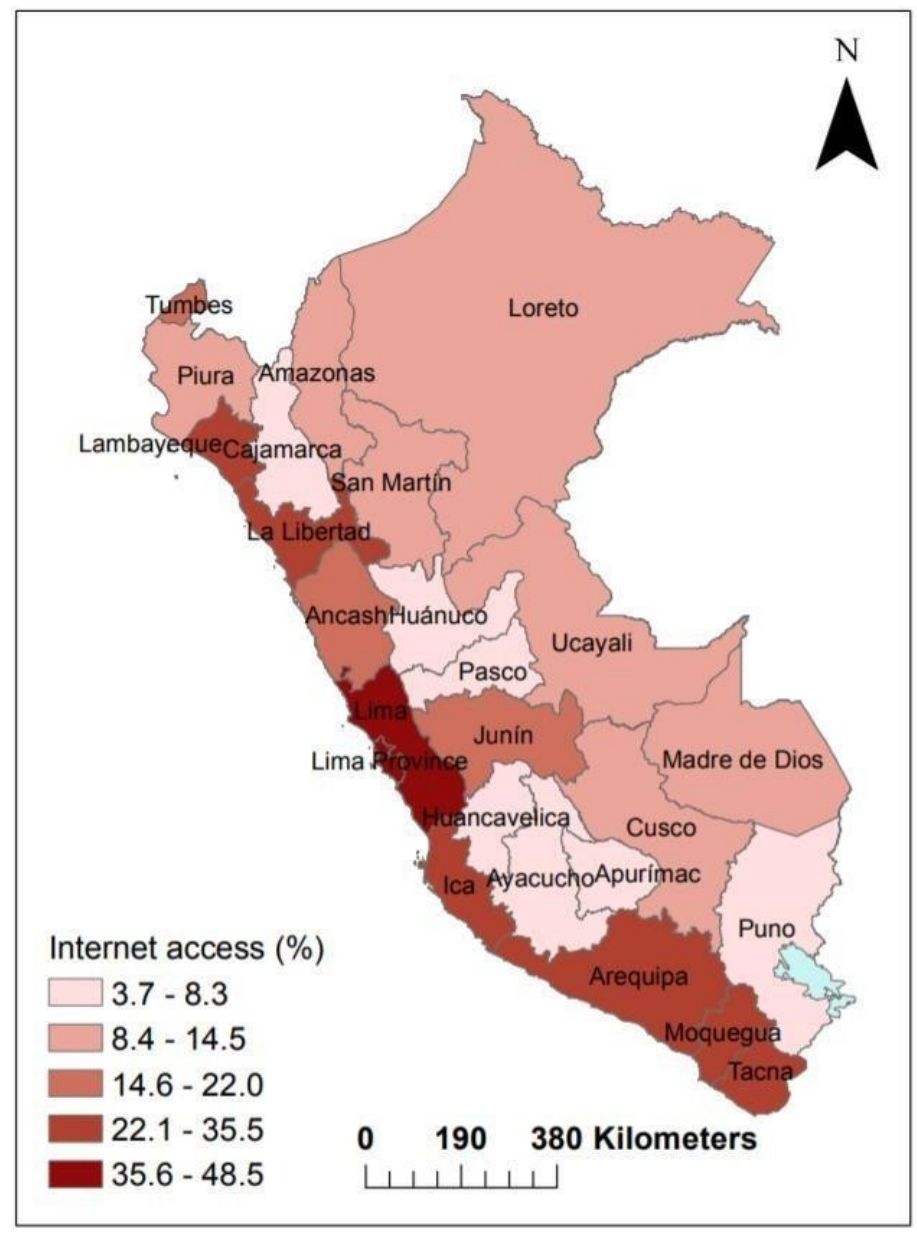

Fig. 1. Heat Map of Provinces in Peru with Internet Access.

of the population 6 years of age and older that has access to the Internet in Peru in 2016 [20].

Another important tool in the present investigation is the use of the cellular phone as the means to host the application by which the development of the courses or videoconferences would take place. As we can see in Fig. 2, the INEI gives us the following data about households in Peru that will have at least one smartphone at home by 2016 [20].

\section{WhatsApp}

A fast messaging experience used as an educational support tool in various aspects of connectivity. With an easy structure, basic platform for the use of this tool is practical and easy to use.

The main tools of WhatsApp and its functionality for learning are shown in Table I.

\section{Moodle Mobile}

Moodle Mobile is an official application of the Moodle platform, available on digital platforms, such as Windows App Store, Google Play, Market and Apple; allowing you to access it from various devices, such as a cell phone, Tablet, IPad, etc. [21]. 


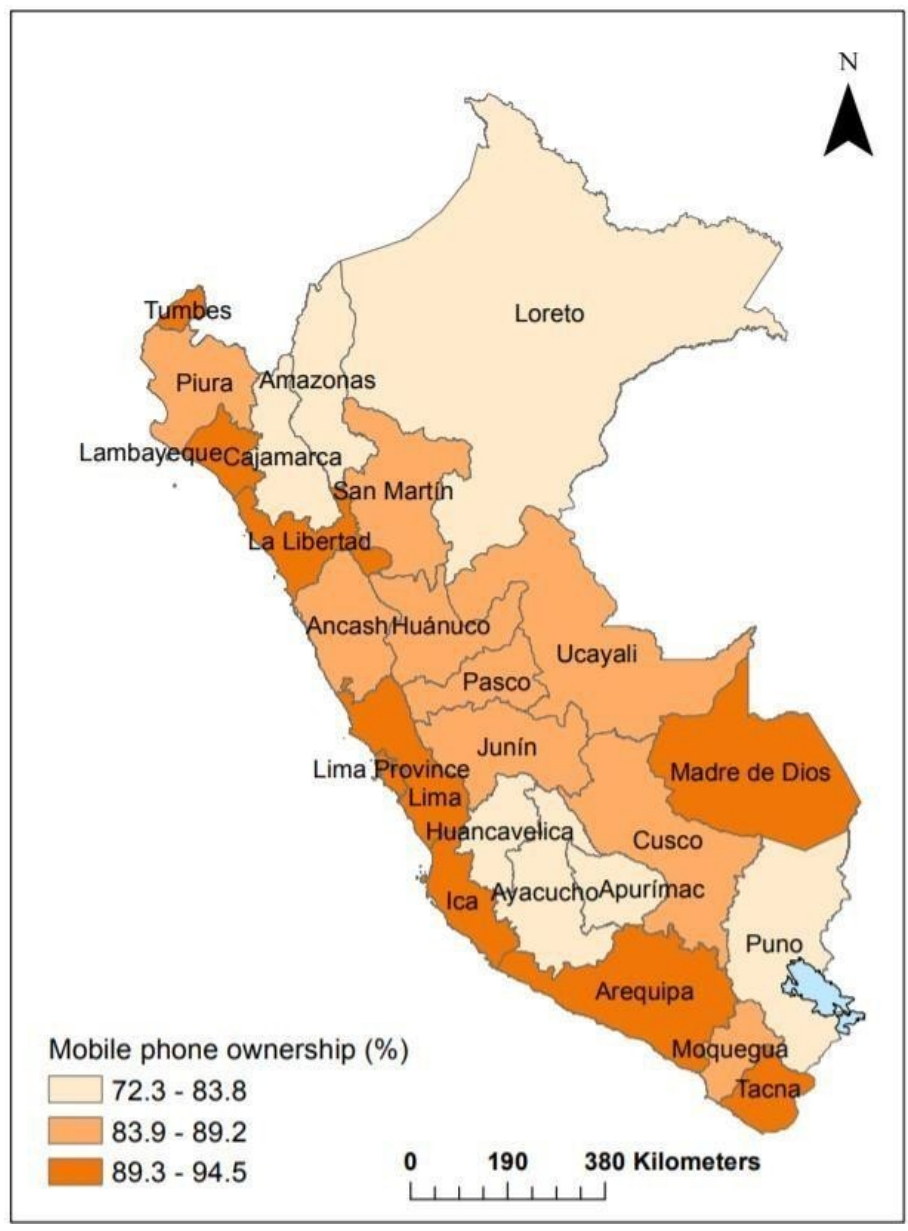

Fig. 2. Heat Map of Provinces in Peru that have at Least one Smartphone.

TABLE I. WhATSAPP's MAIN TOOLS

\begin{tabular}{|l|l|}
\hline TOOL & FUNCTIONALITY \\
\hline \hline New group & $\begin{array}{l}\text { Function created to join contacts in order to share useful } \\
\text { information.\% }\end{array}$ \\
\hline New diffusion & $\begin{array}{l}\text { You can send messages to several contacts at once about } \\
\text { something important or event.\% }\end{array}$ \\
\hline WhatsApp Web & Function that allows you to use it in the browser.\% \\
\hline Featured Messages & Message valued with a star as it has a conversation value.\% \\
\hline Adjustments & $\begin{array}{l}\text { Account privacy settings, chats, notifications and storage } \\
\text { data.\% }\end{array}$ \\
\hline
\end{tabular}

As you can see in Fig. 3, Moodle Mobile can offer the same functions as if it were a desktop, where you can all your content, courses, notes, etc.

Moodle allows us to build systems as complex as an ERP. Moreover, several activities can be carried out that will allow a very close interaction with students and teachers, such as: student and teacher collaborations, peer review and mobile learning, since it will allow them to download and configure the application [22].

Among the outstanding features that Moodle Mobile has, are:

- $\quad$ Contact with your course participants.

- Access their courses and download their contents; as

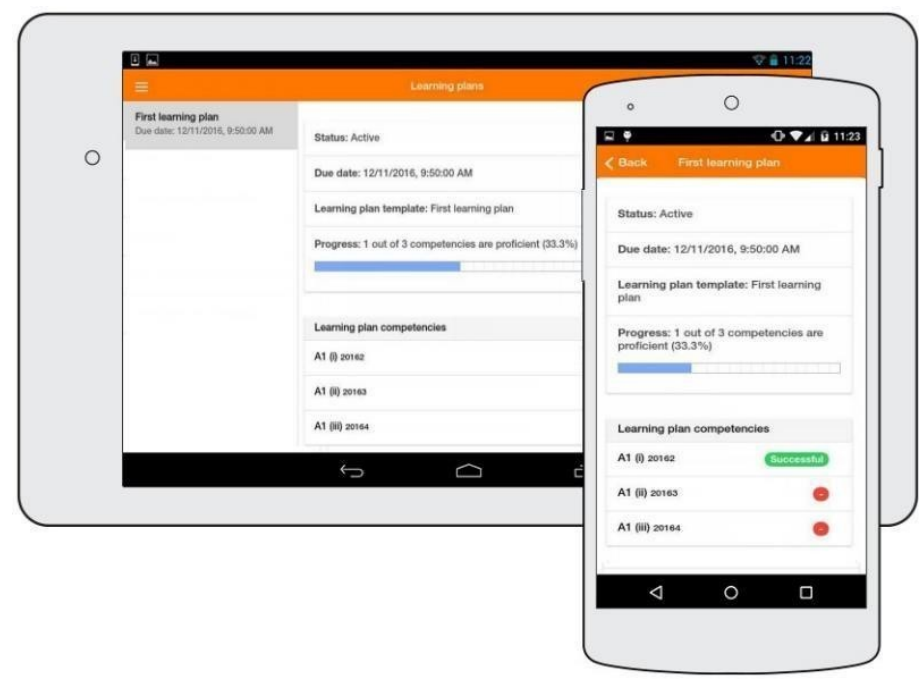

Fig. 3. Moodle Mobile Interface.

well as monitor their own processes.

- Access links to view your course grades.

- Keeps up to date with events with the calendar.

- Feedback to teachers through surveys.

- Exams on the same cell phone.

- Learning plans for the student to check their progress.

- Teachers can grade assignments in real time.

\section{E. Zoom}

Tools that allow you to work efficiently and at any time wherever you are and in an organized way to deal with the problems that arise are various collective connectivity platforms to make a virtual meeting so if you want to manage this environment is necessary to know the aspects of them and their updates that allow us to develop various expectations [23].

As shown in Table II, there are Zoom tools that are useful when conducting a class by video conference and thus be able to make the class dynamic.

TABLE II. ZOOM TOOLS

\begin{tabular}{|l|l|}
\hline TOOL & FUNCTIONALITY \\
\hline \hline Scheduling a meeting & Allows for teleworking, videoconferencing.\% \\
\hline Recording a meeting & Collect data from meetings held.\% \\
\hline Sharing a screen & $\begin{array}{l}\text { Allows several participants to do so simultane- } \\
\text { ously.\% }\end{array}$ \\
\hline Streaming & Broadcast live.\% \\
\hline Virtual blackboard & Enable a blank slate for writing or drawing.\% \\
\hline Live Chat & Participations through a chat.\% \\
\hline Management of participants & $\begin{array}{l}\text { Enable and disable audio and video for partici- } \\
\text { pants. } \%\end{array}$ \\
\hline Virtual backgrounds & Allows the use of a virtual background.\% \\
\hline
\end{tabular}

The added value of these tools is the maximum use of the experiences that allow to solve the problems of academic connectivity among others since they facilitate the generation of new knowledge creating a programmed environment with generations of new connections [22]. 
As shown in Fig. 4, the representation of the basic zoom tools and their easy interaction.

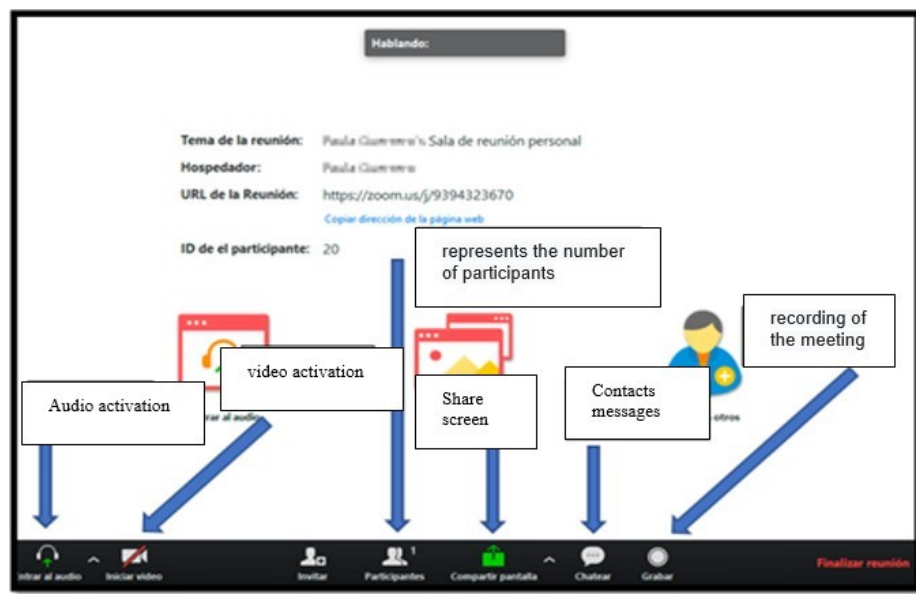

Fig. 4. Zoom Platform Tools

Besides being a free application (the basic functions), its architecture is designed to be as simple as possible, so it is not necessary to have a user's manual.

\section{F. Google Meet}

Meet is more focused on schools and businesses, is paid for and accessed from a corporate Google Suite Center account, and generates more options such as: Encrypted account, the participants can reach 100 or more depending on the plan that has been activated, helps you record meetings so you can share them and send connection links to announce the video call [24].

Google Meet is fully integrated with Google Suite and this makes it possible to join meetings directly from a Calendar event. The following Fig. 5 shows the features of the Meet interface.

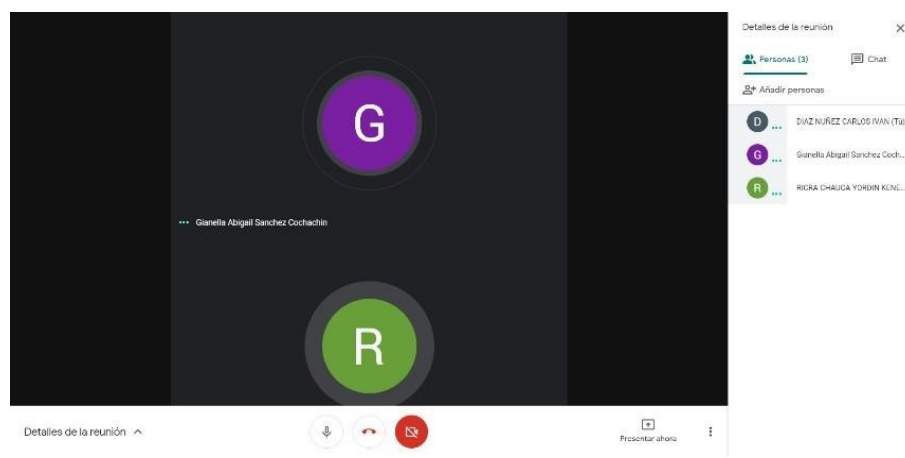

Fig. 5. Graph of Google Meet Features.

A very new feature of Google Meet is that, since May 4th 2020, Meet is available for free on the website meet.google.com and through its mobile applications [25].

Some features of Meet are that it allows screen sharing with more control and integrates screen layouts that suit users. A security feature is that the meeting host can admit or deny entry to a meeting, as well as mute or delete participants. Another is that only Google Account users join meetings, not other users.

\section{RESUlTS AND Discussions}

As for the teachers surveyed, the following results were obtained:

- $100 \%$ ensures that they are capable of working with mobile applications.

- Its objectives for the 2020-I semester were $100 \%$ fulfilled.

- $68 \%$ spend more than 4 extra hours than usual to prepare their classes, while $16 \%$ spend between 2 and 4 hours, and the other $16 \%$ less than 2 hours.

- $\quad 80 \%$ consider that they highly need to strengthen their digital skills, while $20 \%$ do not.

- Most teachers have mastered the Zoom, Google Meet, and WhatsApp tools, as shown in Fig. 6.

- Teachers say they always use digital tools with their students, as shown in Fig. 7.

- $66.7 \%$ of the respondents stated that the greatest difficulty during the online classes was pedagogical, while the rest had other inconveniences, as shown in Fig. 8.

Currently the use of mobile applications such as Zoom, meet, WhatsApp, Moodle has been spread. On a scale of 1 to 5 , mention the handling of each one, where 1 is null and 5 is totally.

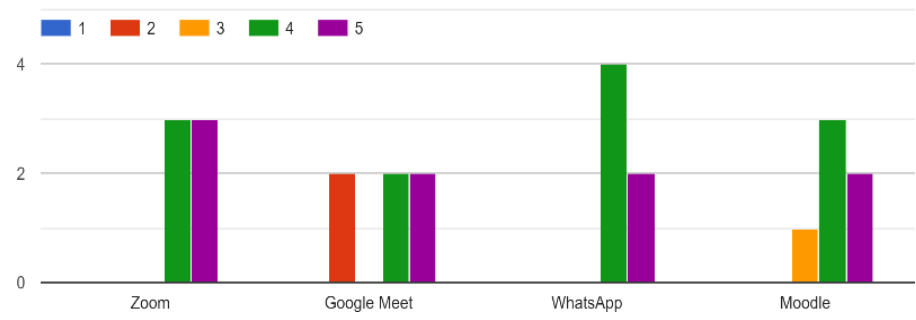

Fig. 6. Question about the use of Mobile Applications.

Please rate the following tools indicating the level of use of each one during online classes:

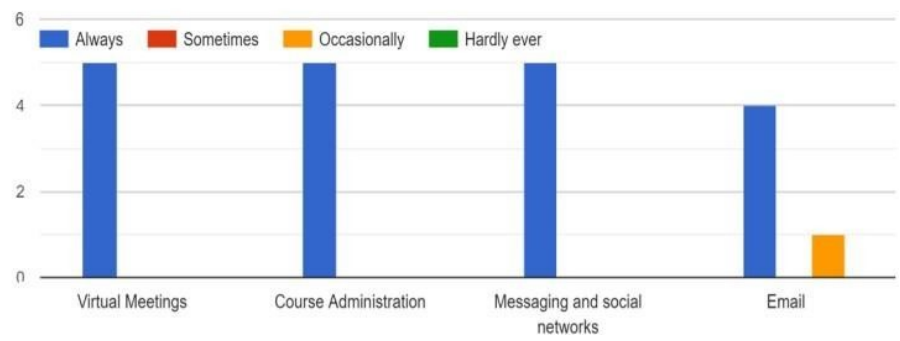

Fig. 7. Question about the use of Digital Tools.

As for the students surveyed, the following results were obtained:

- $67 \%$ consider that their teachers are trained to deal with virtual classes. 
Which of the following variables do you consider to have been the most difficult during online classes?
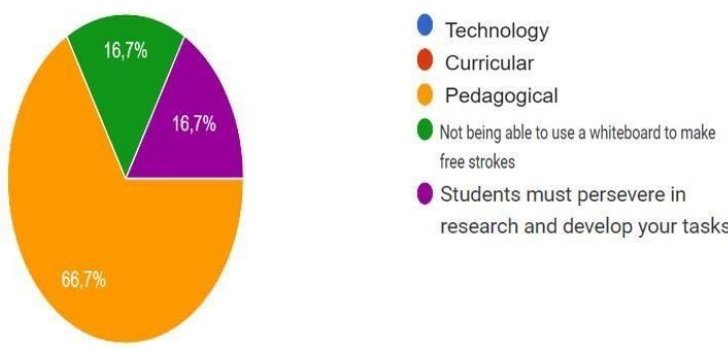

Fig. 8. Question about Difficulties in Online Classes.

- $57 \%$ say that their teachers have a high level of mastery of Moodle, Zoom, WhatsApp or Google Meet, while $47 \%$ consider it low.

- $53 \%$ are sure that mobile applications help them highly in their virtual teaching, while $40 \%$ consider it low, and only $7 \%$ interpret it as very high.

- $67 \%$ dedicate more than 4 hours of extra time than usual to their university work, while $27 \%$ dedicate between 2 and 4 hours, and the other $6 \%$ less than 2 hours.

- $93 \%$ consider that they do need to strengthen their digital skills in virtual environments, while only $7 \%$ do not.

- Most students report medium to high proficiency in the Zoom, Google Meet, and WhatsApp tools, as shown in Fig. 9.

- $87 \%$ of respondents say that mobile do motivate them for virtual learning.

Currently the use of mobile applications such as Zoom, Meet, WhatsApp and Moodle has spread. On a scale of 1 to 5 , mention the handling of each of them, where 1 is null and 5 is very high.

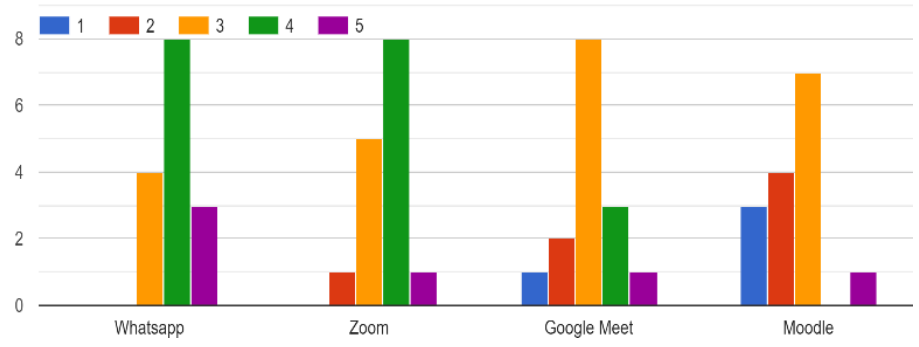

Fig. 9. Graph on the Question of use of Mobile Applications.

On the other hand, the percentages provided by INAI tell us that, although there are differences in purchasing power between one department and another, most households in Peru will have a cell phone at home by 2018 , since they exceed $70 \%$; this means being viable to transmit education in the country.
As we can see in Fig. 1, the difference in internet access is great between some departments and others. For example, while departments like Lima, Ica or the province of Callao, have a great advantage in terms of people who have access with more than 50\%; others like Amazonas, Apurimac or Cajamarca, can barely reach $25 \%$ of their inhabitants. Making it clear that distance education can be given better in some regions of the country than in others.

As for the use of Moodle Mobile, it has been successful in implementation and use for the academic environment. For example, a study carried out on its use indicates that most students who used the tool did so more frequently in looking at the courses or checking the grades obtained, while the discussion forum was the least busy [16]. As can be seen in Fig. 10.

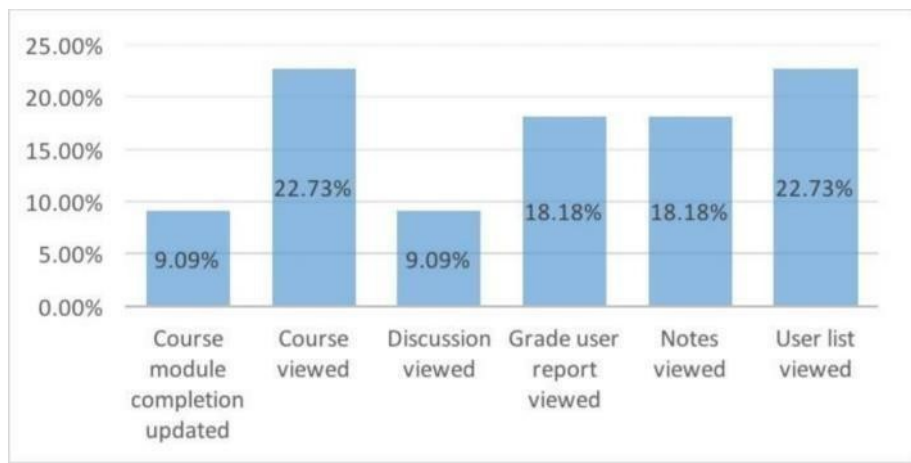

Fig. 10. Using the Moodle Mobile Tool.

In addition, the same study with a sample of 100 students, states that more than half saw it as a very easy tool to use for their courses [26], as shown in Fig. 11.

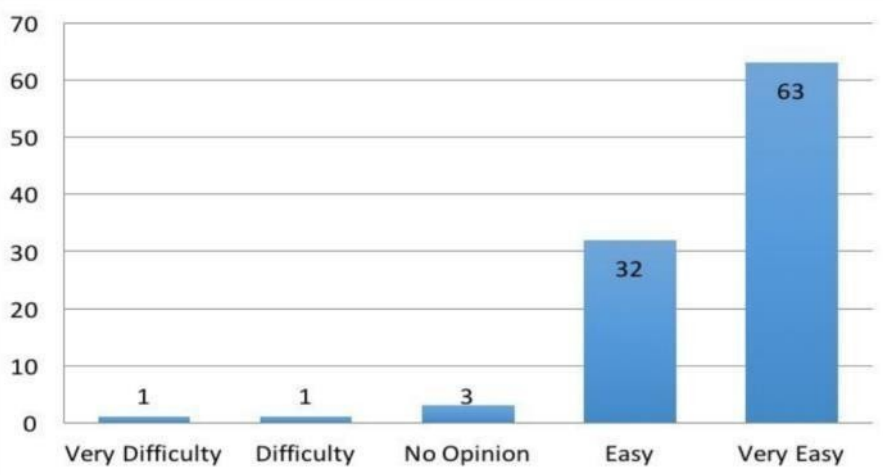

Fig. 11. Difficulty level of the Moodle Mobile Tool.

In a 2018 study, the use of WhatsApp as a means of information exchange for the academic environment was very satisfactory among university students, as they used it for academic purposes as shown in Fig. 12.

One of the most shocking questions was about the use to which it was put. As shown in Fig. 13, it mentions most frequently for records management, followed by group management.

In the XI International Congress of a University the use of the Zoom tool in the courses is very useful and beneficial for 


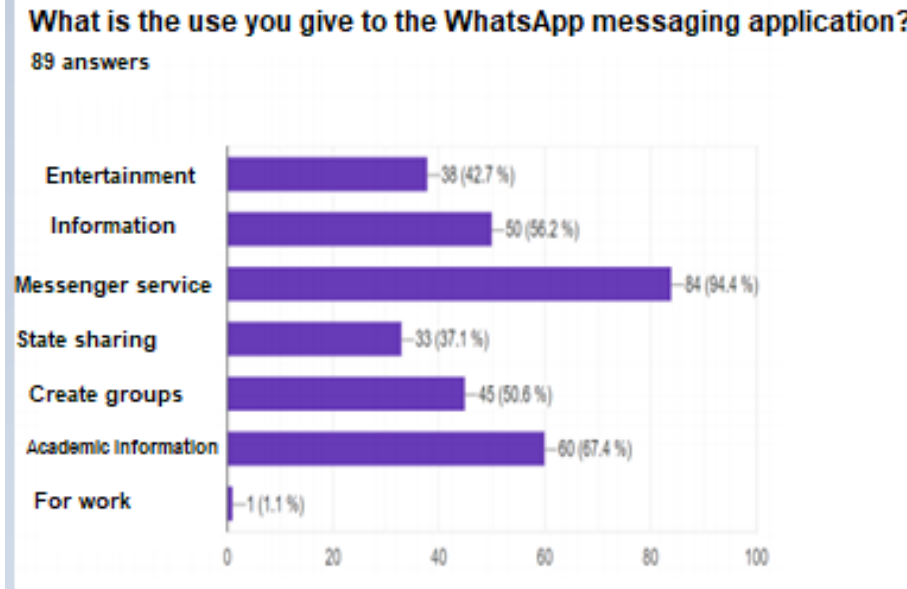

Fig. 12. . What use is Given to the WhatsApp Messaging Application?

\section{What are the academic uses of WhatsApp?}

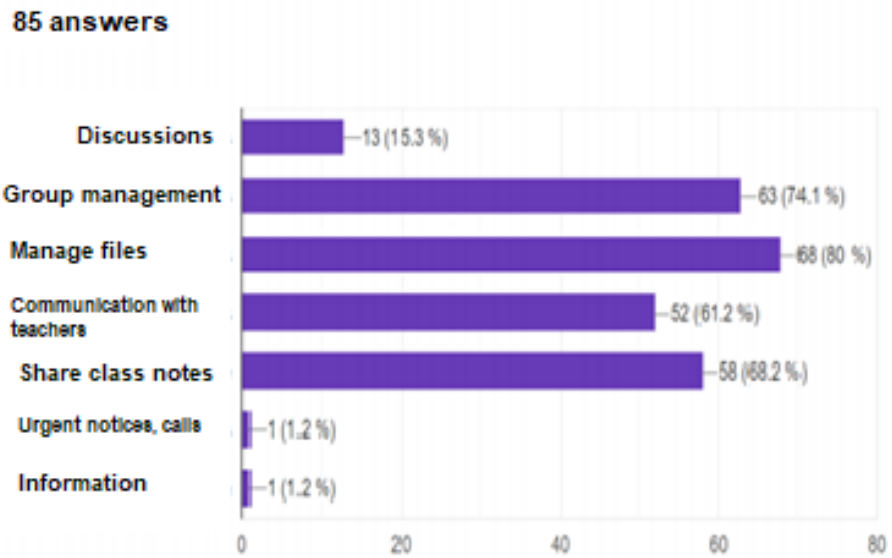

Fig. 13. Academic uses you Give WhatsApp?

the students since they are done through the videoconferences and there is enough contact with the teacher.

Another study mentions the e-learning [27] strategy of many institutions regarding the use of the Zoom and Google Meet application in education. Showing as a result as shown in Fig. 14. That the two are compatible with respect to usability, clarity and user interface.

Another 2019 study from a Latin American journal of social communication [28], mentions the good use of the WhatsApp tool in university students for academic purposes as shown in Fig. 15.

As you can relate, every year more students are using this technology tool, WhatsApp, for academic purposes and are using it for more university subjects.

In addition, Google Meet ranks among the most user friendly applications, as shown in Fig. 16.
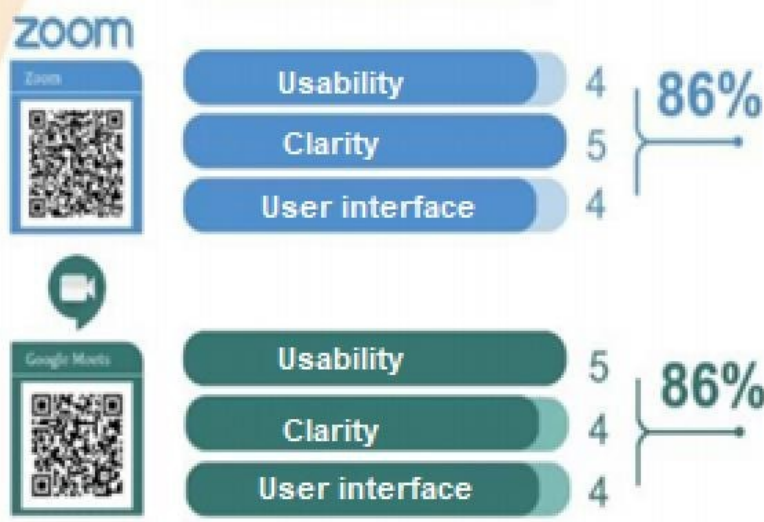

Fig. 14. Zoom and Google Meet Academic Support Strategy.

Graph 14: Use WhatsApp for academic purposes? Do you share links related to your studies? Do you belong to any group related to your studies?
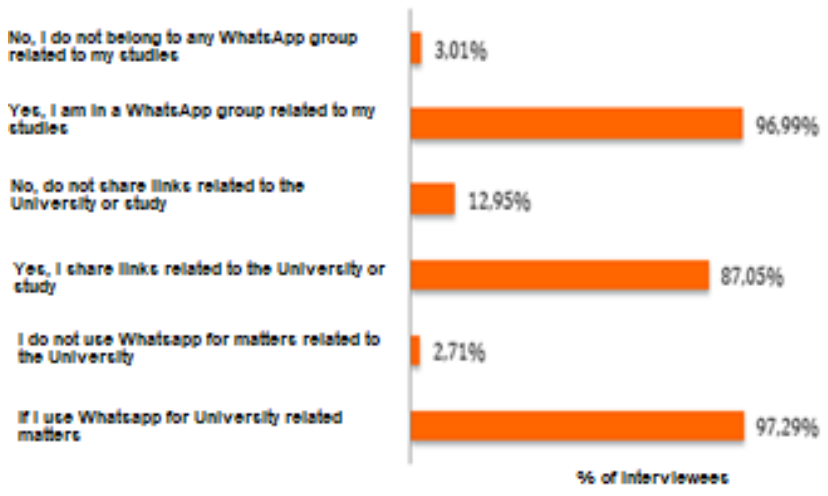

Fig. 15. Do you use WhatsApp for Academic Purposes?

\begin{tabular}{|c|c|c|c|c|c|}
\hline & 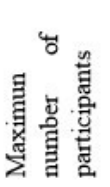 & 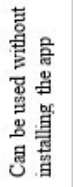 & 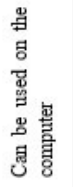 & 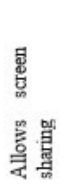 & 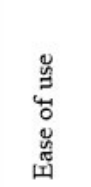 \\
\hline JITSI MEET & unlimited & $\checkmark$ & $\checkmark$ & $\checkmark$ & $\star \star \star \star \star \star$ \\
\hline GOOGLE MEET & 100 & $\checkmark$ & $\checkmark$ & $\checkmark$ & $\star \star \star \star \star$ \\
\hline FACETIME & 32 & & $\checkmark$ & & $\star \star \star \star \star$ \\
\hline GOOGLE DUO & 12 & $\checkmark$ & $\checkmark$ & & $\star \star \star \star \star$ \\
\hline HOUSEPARTY & 8 & $\checkmark$ & $\checkmark$ & $\checkmark$ & $\star \star \star \star \star$ \\
\hline DISCORD & 25 & $\checkmark$ & $\checkmark$ & $\checkmark$ & $\star \star \star \star$ \\
\hline HANGOUTS & 10 & $\checkmark$ & $\checkmark$ & & $\star \star \star \star$ \\
\hline WHATSAPP & 8 & & & & $\star \star \star \star$ \\
\hline MICROSOFT TEAMS & $\begin{array}{l}\text { Between } 10 \\
\text { and } 10.000\end{array}$ & $\checkmark$ & $\checkmark$ & $\checkmark$ & $\star \star \star$ \\
\hline ZOOM CLOUD MEETINGS & 100 & $\checkmark$ & $\checkmark$ & $\checkmark$ & $\star \star \star$ \\
\hline SNAPCHAT & 16 & & & & $\star \star \star$ \\
\hline SKYPE & 10 & $\checkmark$ & $\checkmark$ & $\checkmark$ & $\star \star \star$ \\
\hline INSTAGRAM & 6 & & & & $\star \star \star$ \\
\hline
\end{tabular}

Fig. 16. Graph Representing the Ease of use of Google Meet. 


\section{CONCLUSION AND FUTURE WORK}

In conclusion, regarding the results of the survey applied to both teachers and students of the University of Sciences and Humanities, m-learning is already in university and many of the teachers handle very well the mobile applications mentioned in the survey for virtual teaching. In addition, they are in constant communication with students through the applications, strengthening the teaching provided to them. Also, the expectations that were set for the semester taught were met, using the mobile applications in university teaching. On the other hand, teachers have encountered pedagogical difficulties during the development of their classes, so their improvement is a short term proposal. As for the students, they mentioned that their teachers were trained for m-learning through mobile applications, they also mentioned that using these tools help them in their learning, they are more time in constant communication with their teachers and that motivates them to continue learning even more.

The use of mobile applications in higher education has a great impact on university students, since as mentioned above in a study of the Peruvian population, there is a large percentage of the population that has a mobile device, has access to the Internet and makes use of it. In addition, many universities have conducted studies testing the use of these technological tools such as WhatsApp, Moodle Mobile, Zoom, and Google Meet in their virtual teachings and have obtained great results, academically. It is suggested as future work that a comparison is made of the impact of the use of mobile applications in university teaching in the classroom in physical, blended and remote form.

\section{REFERENCES}

[1] J. C. Yáñez-Luna and M. Arias-Oliva, "M-learning: aceptación tecnológica de dispositivos móviles en la formación online," Revista Tecnología, Ciencia y Educación, no. 10, 2018.

[2] A. A. Vacas, J. I. N. González, and S. Á. Sánchez, "Uso de una app móvil para evaluar la calidad de la enseñanza superior," Prisma Social: revista de investigación social, no. 27, pp. 65-85, 2019.

[3] J. S. Mtebe and A. W. Kondoro, "Using mobile moodle to enhance moodle $1 \mathrm{~ms}$ accessibility and usage at the university of dar es salaam," in 2016 IST-Africa Week Conference, 2016, pp. 1-11.

[4] S. I. Herrera and M. C. Fénnema, "Tecnologías móviles aplicadas a la educación superior," in XVII Congreso Argentino de Ciencias de la Computación, 2011.

[5] F. Portilla and C. Saussure, "El uso del smartphone como herramienta para la búsqueda de información en los estudiantes de pregrado de educación de una universidad de lima metropolitana," Educación, vol. 25, no. 49, pp. 29-44, 2016.

[6] C. J. Fabián Coronel, "M-learning en el rendimiento académico de estudiantes de la escuela profesional de ingeniería de sistemas y computación de la universidad peruana los andes," 2019.

[7] A. García and E. Vidal, "Mobile-learning experience as support for improving the capabilities of the english area for engineering students," in 2019 International Conference on Virtual Reality and Visualization (ICVRV). IEEE, 2019, pp. 202-204.

[8] R. Arias-Marreros, K. Nalvarte-Dionisio, and L. Andrade-Arenas, "Design of a mobile application for the learning of people with down syndrome through interactive games," International Journal of Advanced Computer Science and Applications, vol. 11, no. 11, 2020. [Online]. Available: http://dx.doi.org/10.14569/IJACSA.2020.0111187

[9] A. García and E. Vidal, "Mobile-learning experience as support for improving the capabilities of the english area for engineering students," in 2019 International Conference on Virtual Reality and Visualization (ICVRV). IEEE, 2019, pp. 202-204
[10] C. Chilivumbo, "Mobile e-learning: The choice between responsive/mobile websites and mobile applications for virtual learning environments for increasing access to higher education in malawi," in 2015 IST-Africa Conference. IEEE, 2015, pp. 1-15.

[11] A. F. Azmi, R. Nuravianty, T. I. Nastiti, and D. I. Sensuse, "Using social networking sites for learning experiences by indonesian university students," in 2018 International Conference on Advanced Computer Science and Information Systems (ICACSIS), 2018, pp. 177-182.

[12] D. Carrillo and J. Seki, "Rural area deployment of internet of things connectivity: Lte and lorawan case study," in 2017 IEEE XXIV International Conference on Electronics, Electrical Engineering and Computing (INTERCON), 2017, pp. 1-4.

[13] E. W. Johnson, D. Tougaw, J. D. Will, and A. Kraft, "Distance learning: teaching a course from a remote site to an on-campus classroom," in Proceedings Frontiers in Education 35th Annual Conference, 2005, pp. F1H-1.

[14] H. Najafi and A. Tridane, "Improving instructor-student communication using whatsapp: A pilot study," in 2015 International Conference on Developments of E-Systems Engineering (DeSE), 2015, pp. 171-175.

[15] J. Sutterlin, "Learning is social with zoom video conferencing in your classroom," ELearn, vol. 2018, no. 12, 2018.

[16] H. R. Calle and S. N. Isidro, "Use of a virtual platform as a supporting element for the acquisition of basic mathematical skills in engineering students," in 2013 8th Iberian Conference on Information Systems and Technologies (CISTI), 2013, pp. 1-4.

[17] J. Byrne, M. Furuyabu, J. Moore, and T. Ito, "The unexpected problem of classroom video conferencing: An analysis and solution for google hangouts and jitsi meet," Journal of Foreign Language Education and Technology, vol. 5, no. 2, 2020.

[18] F. M. Amin and H. Sundari, "Efl students' preferences on digital platforms during emergency remote teaching: Video conference, lms, or messenger application?" Studies in English Language and Education, vol. 7, no. 2, pp. 362-378, 2020.

[19] J. Y. Ardila Muñoz and E. M. Ruiz Cañadulce, "Three dimensions for learning management system (lms) evaluation," Zona Próxima, no. 22, pp. 69-86, 2015.

[20] C. Sotomayor-Beltran and L. Andrade-Arenas, "A spatial assessment on internet access in peru between 2007 and 2016 and its implications in education and innovation," in 2019 IEEE 1st Sustainable Cities Latin America Conference (SCLA). IEEE, 2019, pp. 1-4.

[21] C. Malinchi, A. Ciupe, S. Meza, and B. Orza, "A mobile exploration solution for virtual libraries in higher education," in 2017 IEEE 17th International Conference on Advanced Learning Technologies (ICALT), 2017, pp. 490-492.

[22] K. A. Smith, "Cooperative learning: Making "groupwork" work," New directions for teaching and learning, vol. 1996, no. 67, pp. 71-82, 1996.

[23] J. Wu, M. May, and C. Yang, "A moodle-based e-learning framework to conduct the manipulation skill training for an enterprise resource planning system," in 2015 IEEE 7th International Conference on Engineering Education (ICEED). IEEE, 2015, pp. 118-123.

[24] A. Minina and K. Mabrouk, "Transformation of university communication strategy in terms of digitalization," in 2019 Communication Strategies in Digital Society Workshop (ComSDS), 2019, pp. 117-120.

[25] A. Tabot and M. Hamada, "Mobile learning with google app engine," in 2014 IEEE 8th International Symposium on Embedded Multicore/Manycore SoCs, 2014, pp. 63-67.

[26] M. M. Ujakpa, D. Heukelman, V. K. Lazarus, P. Neiss, and G. D. Rukanda, "Using whatsapp to support communication in teaching and learning," in 2018 IST-Africa Week Conference (IST-Africa), 2018, pp. Page 1 of 6-Page 6 of 6.

[27] C. Castro-Vargas, M. Cabana-Caceres, and L. Andrade-Arenas, "Impact of project-based learning on networking and communications competences," International Journal of Advanced Computer Science and Applications, vol. 11, no. 9, 2020. [Online]. Available: http://dx.doi.org/10.14569/IJACSA.2020.0110957

[28] A. Al-Omary, W. M. El-Medany, and K. J. E. Isa, "The impact of sns in higher education: A case study of using whatsapp in the university of bahrain," in 2015 Fifth International Conference on e-Learning (econf), 2015, pp. 296-300. 